\title{
EFFECT OF INSULIN-LIKE GROWTH FACTOR-I AND EPIDERMAL GROWTH FACTOR ON IN VITRO EMBRYO PRODUCTION IN CATTLE
}

\author{
NERMEEN A. HELMY* ${ }^{*}$ and B.R. ABD EL-HALIM ${ }^{* *}$ \\ * Departments of Physiology, Faculty of Veterinary Medicine, Beni-Suef University, Egypt \\ ** Department of Theriogenology, Faculty of Veterinary Medicine, Beni-Suef University, Egypt \\ Email: drbakarwa@yahoo.com
}

\section{ABSTRACT}

Received at: 19/12/2014

The purpose of this study was to investigate the effect of supplementing in vitro maturation medium and culture medium with insulin-like growth factor-I (IGF-I), epidermal growth factor (EGF) and a combination of them on the development of in vitro-matured and fertilized (IVM/IVF) bovine oocytes, as well as their

Accepted: 12/2/2014 developmental rate to cleavage and blastocyst stages. For this purpose, 464 bovine ovaries were collected from Beni Suef abattoir; oocytes were aspirated and used for in vitro maturation and subsequent embryo development. The current results revealed that supplementing maturation and culture media with a combination of IGF-I and EGF was the best treatment for improving rates of IVM, IVF, cleavage and blastocyst development. Addition of IGF-I or EGF into maturation medium had insignificant effect on IVM rate but significantly enhanced subsequent embryonic development as compared to control. Moreover, including IGF-I in culture medium significantly improved cleavage, morula and blastocyst rate as compared to EGFgroup.

Key words: Insulin-like growth factor-I, epidermal growth factor, in vitro embryo production, cattle

\section{INTRODUCTION}

In vitro maturation of bovine oocytes involves removal of prophase I oocytes (together with surrounding cumulus cells) from antral follicles and their culture for 20 to $24 \mathrm{hrs}$. (Galli et al., 2003). During this interval, oocytes extrude their first polar bodies and reach metaphase II (Gilchrist and Thompson, 2007). Supplementation of the maturation medium with selected serum, hormones and other active factors markedly enhanced quality of the matured oocyte. Maturation was better aided by the presence of proestrus or estrus cow because, the serum containing high LH concentrations (Brackett and Zuelke, 1993). Further refinement of conditions for in vitro maturation included addition of various growth factors (Brackett, 2001).

A range of polypeptide growth factor ligands and their receptors have been found to be expressed and produced in the reproductive tract or the preimplantation embryo, in particular EGF and IGF-I and II. Growth factors and cytokines have very important regulatory role during pregnancy (Block et al., 2003 and Spencer et al., 2008). Insulin and insulin like growth factors are major factors that regulate oocytes maturation by acting synergistically with FSH as autocrine and paracrine modulators of granulosa cells, thereby, promoting mitogenesis, steroidogenesis and protein synthesis (Spanos et al.,
2000 and Zicarelli and Gasparrini, 2004) leading to enhanced oocyte maturation, fertilization and embryo development to blastocyst stage (Pawshe et al., 1998 and Purohit et al., 2005). IGF-I promotes oocyte maturation and reduces apoptosis during early human preimplantation embryos (Kawamura et al., 2005 and Neira et al., 2007). Moreover, IGF-I and II are expressed and produced in ruminant embryos from the zygote stage to implantation in the ICM and in the trophoblast; they then continue to be expressed until at least Day 30 of gestation (Martal et al., 1998). In this respect, the addition of IGF-I and II to the culture medium appears to be beneficial as they increase the number of embryos that develop to blastocyst stage in human, mouse, porcine, ovine, and bovine (Watson et al., 1994; Spanos et al., 2000; Glabowski et al., 2005 and Spencer et al., 2008).

Epidermal growth factor stimulates DNA synthesis in cumulus cells (Khamsi and Armstrong, 1997), pattern of protein neosynthesis (Lonergan et al., 1996), production of tissue plasminogen activator (tPA) and urokinase plasminogen activator (uPA) by cumulus cells which stimulates oocyte maturation (Park et al., 1999). Moreover, studies in mouse, rat, human, porcine, and bovine have demonstrated that EGF stimulates in vitro maturation (Reed et al., 1993; Lonergan et al., 1996; Lighten et al., 1997 and Rieger et al., 1998). 
Therefore, the current study aimed to clarify the effect of IGF-I and/or EGF supplementation during in vitro maturation or culture on the maturation and fertilization of bovine oocytes as well as their developmental rate to cleavage and blastocyst.

\section{MATERIALS and METHODS}

All reagents for media preparation were purchased from Sigma Chemical Co. (Saint Louis, MO, USA). To study the effect of growth factors on bovine in vitro embryo production, two separate experiments were done: First experiment: 243 cattle ovaries were used. During maturation, the oocytes were subjected to 4 treatments; Group 1 (Control: maturation medium "MM" alone), Group 2 (MM+ IGF-I; 100 $\mathrm{ng} / \mathrm{ml}$ ), Group 3 (MM+ EGF; $20 \mathrm{ng} / \mathrm{ml})$ and Group 4 (MM+ IGF-I+ EGF).

Second experiment: 221 cattle ovaries were used and the same treatments of the first experiment were implemented during culture of embryos.

\section{Ovaries collection and oocyte recovery}

Cattle ovaries, in warm sterile saline supplemented with $50 \mu \mathrm{g} / \mathrm{ml}$ gentamycin in insulated container were transported to the laboratory within $1 \mathrm{hr}$ of slaughter. Upon arrival, the ovaries were washed repeatedly in normal saline, trimmed free of extraneous tissue and rinsed in normal saline. The cumulus-oocytes complexes (COCs) were recovered from follicles by the slicing method and subsequently washed three times in tissue culture medium 199 (TCM-199) supplemented with $50 \mu \mathrm{g} / \mathrm{ml}$ gentamycin sulfate and $5 \mu \mathrm{l} / \mathrm{ml} \mathrm{L}$-glutamine (washing medium). The COCs were assessed morphologically, using a low-power (X40) stereomicroscope, and only those having evenly granulated cytoplasm and completely surrounded by cumulus cells were selected for in vitro maturation (Pawshe et al., 1994).

\section{In vitro maturation}

COCs were washed twice in TCM-199 supplemented with $10 \% \mathrm{FCS}, 50 \mu \mathrm{g} / \mathrm{ml}$ gentamycin sulfate and 5 $\mu \mathrm{l} / \mathrm{ml}$ L-glutamine (Nedambale et al., 2006) then transferred to $50 \mu \mathrm{l}$ TCM-199 maturation medium supplemented with $10 \% \mathrm{FCS}, 50 \mu \mathrm{g} / \mathrm{ml}$ gentamycin sulfate and $5 \mu \mathrm{l} / \mathrm{ml}$ L-glutamine, 0.2 i.u FSH, 2.0 i.u HCG and $1.0 \mu \mathrm{g} \mathrm{E}_{2} / \mathrm{ml}$ (Choi et al., 2001).

The oocyte - containing droplet (10 cells) was covered with $4 \mathrm{ml}$ sterile mineral oil to prevent evaporation then incubated for maturation in $\mathrm{CO}_{2}$ incubator for $24 \mathrm{hrs}$ (Nedambale et al., 2006) after which they were examined under stereomicroscope (X 100). The assessment of maturation was done by the degree of expansion of cumulus cell mass and extrusion of first polar body into the perivitelline space.

\section{In vitro fertilization (IVF) of oocytes}

Motile spermatozoa were selected using swim-up technique in Sperm - Tyrod's Albumin Lactate Pyruvate medium (S- TALP) supplied with gentamycin sulfate $(50 \mu \mathrm{g} / \mathrm{ml})$ and BSA (SigmaAldrich, USA) fraction-V "essential fatty acid - free" (6 mg / ml) and heparin sodium salt (200 i.u. / ml) for sperm capacitation (Parrish et al., 1986). For this purpose, two straws of frozen bull semen received from Artificial insemination center, Beni Suef, Egypt were used. The selected bovine sperm was resuspended in $1.0 \mathrm{ml}$ of Fertilization Tyrod's, Albumin, Lactate, Pyruvate medium (F-TALP) supplied with $10 \mu \mathrm{g} / \mathrm{ml}$ penicillamine, $50 \mu \mathrm{g} / \mathrm{ml}$ gentamycin sulfate and $6 \mathrm{mg} / \mathrm{ml}$ BSA (Younis et al., 1989). Sperm concentration was measured by hemocytometer and a sufficient medium was added to yield the final concentration of $1 \times 10^{6}$ sperm $/ \mathrm{ml}$.

Following maturation, good and excellent mature COCs were washed three times by F-TALP medium then transferred to $50 \mu \mathrm{l}$ droplets of the same medium (5 oocytes / droplet). The oocytes were covered with warm sterile mineral oil then incubated in $\mathrm{CO}_{2}$ incubator for an hour after which the oocytes were inseminated with sperm suspension $(2 \mu \mathrm{l} /$ droplet $)$.

\section{In vitro culture (IVC) of fertilized oocytes}

Twenty four hours following fertilization, the inseminated oocytes were washed 3 times using hepes - TCM 199 " H-TCM " supplemented with $10 \%$ FCS, $50 \mu \mathrm{g} / \mathrm{ml}$ gentamycin sulfate and $5 \mu \mathrm{l} / \mathrm{ml} \mathrm{L}$ glutamine (culture medium) then transferred to droplets of the same medium (5 oocytes / $100 \mu \mathrm{l})$ and incubated in the $\mathrm{CO}_{2}$ incubator with change of the culture medium every 48 hours for 7 successive days (Hammam et al., 1997). The culture media was changed with freshly prepared embryo culture media every $48 \mathrm{hrs}$ and observation was made for cleavage and subsequent development of embryos.

\section{Statistical analysis}

The results obtained for in vitro maturation, fertilization and embryonic development of oocytes were analyzed using SAS user guide (SAS, 2004) to determine ANOVA. Differences were considered significant at $\mathrm{P}<0.05$.

\section{RESULTS}

\section{Effect of IGF-I and EGF in maturation medium on in vitro embryo production:}

The current results revealed that addition of IGF-I + EGF to IVM medium significantly increased IVM rate $(94.3 \pm 0.30 \%)$ as compared to control, IGF-I and EGF groups $(90.5 \pm 2.10,91.3 \pm 0.64$ and $91.9 \pm$ 0.85 , respectively). However, there was no significant increase in the rate of IVM on adding IGF I or EGF. In regards to the effect of IGF-I and EGF on fertilization rate, it was found that addition of IGF-I 
$(69.70 \pm 0.52 \%)$ or $\operatorname{EGF}(69.50 \pm 0.60 \%)$ alone or in combination $(73.04 \pm 0.94 \%)$ significantly enhanced IVF rate than the control group $(63.90 \pm 0.87 \%)$. Similarly, including the maturation medium with IGF-I, or EGF alone or in combination resulted in significantly higher cleavage, morula and blastocyst $\%$ compared to control group. Moreover, Oocytes matured in the presence of IGF-I + EGF had higher rates of cleavage, morula and blastocyst formation than those in IGF-I or EGF groups (Table 1).

Addition of IGF-I alone or in combination with EGF, into cleavage medium, significantly increased cleavage, morula and blastocyst production rates as compared with control and EGF groups (Table 2).

Table 1: Effect of insulin like growth factor and epidermal growth factor in maturation medium on in vitro embryo production $(\mathrm{Mean} \pm \mathrm{SE})$

\begin{tabular}{cccccc}
\hline Treatment & $\begin{array}{c}\text { Maturation } \\
(\%)\end{array}$ & $\begin{array}{c}\text { Fertilization } \\
(\%)\end{array}$ & $\begin{array}{c}\text { Cleavage } \\
(\%)\end{array}$ & $\begin{array}{c}\text { Morula } \\
(\%)\end{array}$ & $\begin{array}{c}\text { Blastocyst } \\
(\%)\end{array}$ \\
\hline Control & $90.5 \pm 2.10^{\mathrm{a}}$ & $63.90 \pm 0.87^{\mathrm{a}}$ & $47.20 \pm 0.70^{\mathrm{a}}$ & $32.30 \pm 0.54^{\mathrm{a}}$ & $13.70 \pm 0.35^{\mathrm{a}}$ \\
\hline IGF-I & $91.3 \pm 0.64^{\mathrm{ab}}$ & $69.70 \pm 0.52^{\mathrm{b}}$ & $50.10 \pm 0.93^{\mathrm{b}}$ & $35.30 \pm 0.72^{\mathrm{b}}$ & $17.20 \pm 0.64^{\mathrm{b}}$ \\
\hline EGF & $91.9 \pm 0.85^{\mathrm{ab}}$ & $69.50 \pm 0.60^{\mathrm{b}}$ & $50.60 \pm 0.84^{\mathrm{b}}$ & $35.70 \pm 0.59^{\mathrm{b}}$ & $16.80 \pm 0.64^{\mathrm{b}}$ \\
\hline IGF+EGF & $94.3 \pm 0.30^{\mathrm{b}}$ & $73.04 \pm 0.94^{\mathrm{c}}$ & $54.20 \pm 0.63^{\mathrm{c}}$ & $37.60 \pm 0.52^{\mathrm{c}}$ & $20.60 \pm 0.86^{\mathrm{c}}$
\end{tabular}

Within the same column values with different superscript letters ( $\mathrm{a}, \mathrm{b}$ and $\mathrm{c}$ ) were statistically different at $(\mathrm{P} \leq 0.05)$. SE: standard error.

Table 2: Effect of insulin like growth factor and epidermal growth factor in culture medium on in vitro embryo production (Mean $\pm \mathrm{SE})$

\begin{tabular}{ccccc}
\hline Treatment & $\begin{array}{c}\text { Fertilization } \\
(\%)\end{array}$ & $\begin{array}{c}\text { Cleavage } \\
(\%)\end{array}$ & $\begin{array}{c}\text { Morula } \\
(\%)\end{array}$ & $\begin{array}{c}\text { Blastocyst } \\
(\%)\end{array}$ \\
\hline Control & $66.90 \pm 1.52$ & $48.40 \pm 0.88^{\mathrm{a}}$ & $32.30 \pm 0.72^{\mathrm{a}}$ & $15.40 \pm 0.46^{\mathrm{a}}$ \\
\hline IGF-I & $64.40 \pm 1.32$ & $54.70 \pm 0.52^{\mathrm{b}}$ & $37.40 \pm 1.14^{\mathrm{b}}$ & $18.60 \pm 0.79^{\mathrm{b}}$ \\
\hline EGF & $64.90 \pm 1.83$ & $48.30 \pm 1.30^{\mathrm{a}}$ & $33.30 \pm 0.88^{\mathrm{a}}$ & $14.90 \pm 0.68^{\mathrm{a}}$ \\
\hline IGF+EGF & $66.50 \pm 1.50$ & $54.80 \pm 0.79^{\mathrm{b}}$ & $37.70 \pm 1.31^{\mathrm{b}}$ & $19.80 \pm 0.68^{\mathrm{b}}$ \\
\hline
\end{tabular}

Within the same column values with different superscript letters ( $a, b$ and $c$ ) were statistically different at $(P \leq 0.05)$.

SE: standard error.

\section{DISCUSSION}

The purpose of this study was to examine the effect of growth factors on early embryonic development. Throughout the study, two types of growth factors; IGF-I and EGF were tested on the basis of their known pleiotropic effects on embryonic development (Eckert and Niemann, 1998; Martal et al., 1998 and Chaouat et al., 2003). The concentrations of growth factors used were according to previous reports suggested that insulin like growth factor-1 (IGF-1) at $100 \mathrm{ng} / \mathrm{ml}$ (Pawshe et al., 1998) and (EGF) $20 \mathrm{ng} / \mathrm{ml}$ (Gupta et al., 2002) are the respective optimum concentrations for oocyte maturation and subsequent development.

Results of the current study showed that IGF-I or EGF added to maturation medium had no significant effect on IVM rate as compared to control while their combination significantly increased in vitro maturation of bovine oocytes. Moreover, addition of IGF-I and / or EGF to the maturation medium significantly enhanced in vitro fertilization, cleavage, morula and blastocyst rates. These results come in accordance with those of Oyamada and Fukui (2004) who used EGF and cysteamine together during IVM and found no positive effect on nuclear maturation but improved cleavage rate and developmental competency of oocyte. In addition, results obtained by Sakaguchi et al. (2000) indicated that the progression of meiosis in bovine oocytes with cumulus cells is accelerated by exposure to combination of IGF-I and EGF in serum-free maturation medium. These results, also, coincide with those obtained by Purohit et al. (2005) and Wani et al. (2012) who recorded significant increase in 
cleavage rate and subsequent embryo development with EGF supplementation in bovine and ovine, respectively. Harper and Brackett (1993) reported that addition of growth factors; EGF and IGF-I had beneficial effect on blastocyst production rate in a number of species. Such beneficial effect may be due to the fact that EGF has been shown to stimulate nuclear and cytoplasmic maturation in a wide variety of species, including mouse, pig, cattle, deer, goat and sheep (Lonergan et al., 1996; Abeydeera et al., 2000; Guler et al., 2000 and Comizzoli et al., 2001) and subsequently enhance blastocyst yields (Park et al., 2004). Insulin like growth factors are major factors that regulate oocytes maturation by acting synergistically with FSH as autocrine and paracrine modulators of granulosa cells, thereby, promoting mitogenesis, steroidogenesis and protein synthesis (Spanos et al., 2000 and Zicarelli and Gasparrini, 2004) leading to enhanced oocyte maturation, fertilization and embryo development to blastocyst stage (Pawshe et al., 1998 and Purohit et al., 2005). Furthermore, IGF-I reduces apoptosis during early human preimplantation embryos (Kawamura et al., 2005 and Neira et al., 2007).

In the second experiment, addition of IGF-I alone or in combination with EGF, into cleavage medium, significantly increased cleavage, morula and blastocyst production rates as compared with control and EGF groups. Neira et al. (2007) reported that addition of $50 \mathrm{ng}$ IGF-I to in vitro culture medium of bovine embryos significantly increased the blastocyst yields after 8 days of embryo culture. On the contrary, media containing EGF did not support embryonic development from 8-cell stage and thereafter, suggesting a possibility of EGF-causing atresia (Monniaux et al., 1997). It is interesting to note that IGF-I and EGF also stimulate embryo development by increasing RNA and DNA synthesis at time of compaction, which is followed by an increase in blastocyst yield in vitro (Brison and Schultz 1997 and Young et al., 2001). IGF-I also stimulates the incorporation of proteins by endocytosis and limits their degradation (Brison and Schultz, 1997). IGF-I increases total cell number in blastocysts exposed to stressors which increases the percentage of blastomeres that undergo apoptosis (Jousan and Hansen, 2007 and Block et al., 2008). IGF-I and EGF have a positive effect on preimplantation of embryo development under detrimental culture conditions of oxidative stress (Kurzava et al., 2004 and Yang et al., 2005).

\section{CONCLUSION}

In conclusion, the supplementation of IGF-1 + EGF together with basic maturation medium and culture medium exerted a positive influence on the progression of oocyte maturation and improved IVF and consequently could be utilized for efficient in vitro embryo production in cattle.

\section{REFERENCES}

Abeydeera, L.R.; Wang, W.H.; Cantley, T.C.; Rieke, A.; Murphy, C.N.; Prather, R.S. and Day, B.N. (2000): Development and viability of pig oocytes matured in protein-free medium containing epidermal growth factor. Theriog., 54: $787-797$.

Block, J.; Drost, M.; Monson, R.L.; Rutledge, J.J.; Rivera, R.M. and Paula-Lopes, FF. (2003): Use of insulin-like growth factor-I during embryo culture and treatment of recipients with gonadotropin releasing hormone to increase pregnancy rates following the transfer of in vitro-produced embryos to heat-stressed, lactating cows. J. Anim. Sci., 81: 1590-602.

Block, J.; Wrenzycki, C.; Niemann, D.; Herrmann, D. and Hansen, PJ. (2008): Effects of insulin-like growth factor-1 on cellular and molecularcharacteristics of bovine blastocysts produced in vitro. Mol. Reprod. Dev. 75: 895-903.

Brackett, B.G. and Zuelke, K.A. (1993): Analysis of factors involved in the in vitro production of bovine embryos. Theriogenology, 39:43-64.

Brackett, B.G. (2001): Advances in animal in vitro fertilization. In: Contemporary Endocrinology: assisted Fertilization and Nuclear Transfer in Mammals. Wolf DP, Zelinski-Wooten M.(Eds.). Humana Press.

Brackett, B.G. and Zuelke, K.A. (1993): Analysis of factors involved in the in vitro production of bovine embryos. Theriogenology, 39: 43-64.

Brison, D.R. and Schultz, R.M. (1997): Apoptosis during mouse blastocyst formation: evidence for a role for survival factors including transforming growth factor alpha. Biol. Reprod., 56: 1088-1096.

Chaouat, G.; Lede'e-Bataille, N.; Dubranchet, S.; Zourbas, S.; Sandra, $O$. and Martal J. Reproductive immunology (2003): Reassessing the Th1/Th2 paradigm? Immunol Lett 2004; 15: $207-214$.

Choi, Y.H.; Takagi, M.; Kamishita, H.; Wijayagunawardane, M.P.; Acosta, T.J.; Miyazawa, K. and Sato, K. (2001): Developmental capacity of bovine oocytes matured in two kinds of follicular fluid and fertilized in vitro. Anim. Reprod. Sci., 50: 27-33.

Comizzoli, P.; Mermillod, P.; Cognie, Y.; Chai, N.; Legendre, $X$. and Mauge, R. (2001): Successful in vitro production of embryos in the red deer (Cervus elaphus) and the sika deer (Cervus nippon). Theriogenology, 55: 649-659. 
Eckert, J. and Niemann, H. (1998): mRNA expression of leukaemia inhibitory factor (LIF) and its receptor subunits glycoprotein 130 and LIFreceptor- beta in bovine embryos derived in vitro or in vivo. Mol. Hum. Reprod., 4: 957-965.

Galli, C.; Duchi, R.; Crotti, G.; Turini, P.; Ponderato, N. and Colleoni, S. (2003): Bovine embryo technologies. Theriogenology, 59: 599-616.

Gilchrist, R.B. and Thompson, J.G. (2007): Oocyte maturation: emerging concepts and technologies to improve developmental potential in vitro. Theriogenology, 67:6-15.

Glabowski, W.; Kurzawa, R.; Wiszniewska, B.; Baczkowski, T.; Marchlewicz, M. and Berlik, $P$. (2005): Growth factors effects on preimplantation development of mouse embryos exposed to tumor necrosis factor alpha. Reprod. Biol., 5: 83-99.

Guler, A.; Poulin, N.; Mermillod, P.; Terqui, M. and Cognie, Y. (2000): Effect of growth factors, EGF and IGF-1, and estradiol on in vitro maturation of sheep oocytes. Theriogenology, 54: 209-218.

Gupta, P.S.; Nandi, S.; Ravindranatha, B.M. and Sarma, P.V. (2002): In vitro maturation of buffalo oocytes with epidermal growth factor and fibroblast growth factor. Ind. J. Anim. Sci., 72: $20-23$.

Hammam, A.M.; Zabaal, M.M. and Sabra, H.A. (1997): Effect of types of media on in vitro maturation, culture and fertilization of buffalo and cattle oocytes. Beni Suef Vet. Med. Res., 5: $242-258$.

Harper, K.M. and Brackett, B.G. (1993): Bovine blastocyst development after in vitro maturation in a defined medium with epidermal growth factor and low concentrations of gonadotropins. Biol. Reprod., 48: 409-416.

Jousan, F.D. and Hansen, P.J. (2007): Insulin-like growth factor-I promotes resistance of bovine preimplantation embryos to heat shock through actions independent of its anti-apoptic actions requiring P13K signaling. Mol. Reprod. Dev., 74: 189-196.

Kawamura, K.; Fukuda, J.; Shimizu, Y.; Kodama, H. and Tanaka, T. (2005): Survival contributes to the anti-apoptotic activities of transforming growth factor alpha in mouse blastocysts through phosphatidylinositol 30-kinase pathway. Biol. Reprod., 73: 1094-1101.

Khamsi, F. and Armstrong, D.T. (1997): Interactions between follicle stimulating hormone and growth factors in regulation of deoxyribonucleic acid synthesis in bovine granulosa cells. Biol. Reprod., 57: 684-688.

Kurzava, R.; Glabowski, T.; Baczkowski, T.; Wiszniewska, B. and Marchlewicz, M. (2004):
Growth factors protect in vitro cultured embryos from the consequences of oxydative stress. Zygote, 12: 231-240.

Lighten, A.D.; Hardy, K.; Winston, R.M. and Moore, G.E. (1997): Expression of mRNA for the insulin-like growth factors and their receptors in human pre-implantation embryos. Mol. Reprod. Dev., 47: 134 - 139.

Lonergan, P.; Carolan, C.; Van Langendonckt, A.; Donnay, I.; Khatier, H. and Mermillod, P. (1996): Role of epidermal growth factor in bovine oocyte maturation and preimplantation embryo development in vitro. Biol. Reprod., 54: $1420-1429$.

Martal, J.; Chêne, N.; Huynh, L.; L'Haridon, R.; Reinaud, P. and Guillomot, M. (1998): A novel subtype I IFN. Structural characteristics, non-ubiquitous expression, structure-function relationships, a pregnancy hormonal embryonic signal and crossspecies therapeutic potentialities. Biochim., 80: 755-777.

Monniaux, D.; Monget, P.; Besnard, N.; Huet, C. and Pisselet, C. (1997): Growth factors and antral follicular development in domestic ruminants. Theriogenology, 47: 3-12.

Nedambale, T.L.; Du, X. and Yang, X.C. (2006): Higher survival rate of vitrified and thawed in vitro produced bovine blastocysts following culture in defined medium supplemented with beta-mercapto-ethanol. Anim. Reprod., Sci. 93: 61-75.

Neira, J.A.; Tainturier, D.; L'Haridon, R. and Martal, J. (2007): Comparative IFN tau secretion after hatching by bovine blastocysts derived ex vivo and completely produced in vitro. Reprod. Domest. Anim., 42: 68-75.

Oyamada, T. and Fukui, Y. (2004): Oxygen tension and medium supplements for in vitro maturation of bovine oocytes cultured individually in a chemically defined medium. J. Reprod. Dev., 50: 107-117.

Park, K.W.; Choi, S.H.; Song, X.X.; Funahashi, H. and Niwa, K. (1999): Production of plasminogen activators (PAS) in bovine cumulus oocyte complexes during maturation in vitro: effect of epidermal growth factor on production of PAS in oocytes and cumulus cells. Biol. Reprod., 61: 298-304.

Park, J.Y.; Su, Y.Q.; Ariga, M.; Law, E.; Jin, S.L. and Conti, M. (2004): EGF-like growth factors as mediators of LH action in the ovulatory follicle. Sci., 303: 682-684.

Parrish, J.J.; Susko-Parrish, J.L.; Leibfried-Rutledge, L.; Crister, E.S.; Eyestone, W.H. and First, N.L. (1986): Bovine in vitro fertilization with frozen-thawed semen. Theriogenology, 25: 591-600.

Pawshe, C.H.; Totey, S.M. and Jain, S.K. (1994): A comparison of three methods of recovery of 
goat oocytes for in vitro maturation and fertilization. Theriogenology, 42: 117-125.

Pawshe, C.H.; AppaRao, K.P. and Totey, S.M. (1998): Effect of insulin-like growth factor I and its interaction with gonadotrophins on in vitro maturation and embryonic development, cell proliferation and biosynthetic activity of cumulus-oocyte complexes and granulosa cell in buffalo. Mol. Reprod. Dev., 49: 277-289.

Purohit, G.N.; Brady, M.S. and Sharma, S.S. (2005): Influence of epidermal growth factor and insulin like growth factor-1 on nuclear maturation and fertilization of buffalo cumulus complexes in serum free media and their subsequent development in vitro. Anim. Reprod. Sci., 87: 229-239.

Reed, M.L.; Estrada, J.L.; Illera, M.J. and Petters, R.M. (1993): Effects of epidermal growth factor, insulin-like growth factor-I, and dialyzed porcine follicular fluid on porcine oocyte maturation in vitro. J. Exp. Zool., 266: 74-78.

Rieger, D.; Luciano, A.M.; Modina, S.; Pocar, P.; Lauria, A. and Gandolfi, F. (1998): The effects of epidermal growth factor and insulin-like growth factor I on the metabolic activity, nuclear maturation and subsequent development of cattle oocytes in vitro. J. Reprod. Fertil., 112: 123-130.

Sakaguchi, M.; Dominko, T.; Leibfried-Rutledge, M.; Nagai, T. and First, N. (2000): A combination of EGF and IGF-I accelerates the progression of meiosis in bovine follicular oocytes in vitro and fetal calf serum neutrali zes the acceleration effect. Theriogenology, 54: 1327-1342.

$S A S$ v 9.1. $S A S^{\circledR}$ 9.1.3 (2004): Qualification tools User's guide. SAS institute Inc, cary, $\mathrm{NC}$, USA.

Spanos, S.; Becker, D.L.; Winston, R.M. and Hardy, $K$. (2000): Anti-apoptotic action of insulin-like growth factor-I during human preimplantation embryo development. Biol. Reprod., 63: 1413 $-1420$.

Spencer, T.E.; Sandra, O. and Wolf, E. (2008): Genes involved in conceptusendometrial interactions ruminants: insights from reductionism and thoughts on holistic approaches. Reprod., 135: 165-179.

Wani, M.Z.; Khan, K.A.; Sofi,, F.A.; Lone, A.A. and Malik, F.A. (2012): Effect of cysteamine and epidermal growth factor (EGF) supplementation in maturation medium on in vitro maturation, fertilization and culturing of embryos in sheep.Small Rumin. Res., 106: $160-164$.

Watson, A.; Watson, P.H.; Arcella-panlilio, P.; Warnes, D.; Walker, S.K. and Shultz, G.A. (1994): Preimplantation development of in vitromatured and in vitro-fertilized ovine zygotes: comparison between coculture on oviduct epithelial cell monolayers and culture under low oxygen atmosphere. Biol. Reprod., 50: 715-724.

Yang, L.; Chavatte-Palmer, P.; Kubota, C.; O'neill, M.; Hoagland, T. and Renard, J.P. (2005): Expression of imprinted genes is aberrant in deceased newborn cloned calves and relatively normal in surviving adult clones. Mol. Reprod. Dev., 71: 431-438.

Younis, A.I.; Brackett, B.G. and Fayer-Hosken, R.A. (1989): Influence of serum and hormones on bovine oocytes maturation and fertilization in vitro. Gamete Res., 23: 189-201.

Young, L.E.; Fernandes, K.; Evoy, T.G.; Butterwith, S.C.; Gutierrez, C.G. and Carolan, C. (2001): Epigenetic change in IGF2R is associated with foetal overgrowth after sheep embryo culture. Nat. Genet., 27: 153-154.

Zicarelli, L. and Gasparrini, B. (2004): Embryo Production in buffalo species. In: Proceedings of the 7thWorld Buffalo Congress, Manila, Philippines, 20-23 October, 157-172.

\section{تأثير عامل النمو شبية الأنسولين وعامل نمو البشرة المضاف الى بيئة النضوج والإخصاب المعملى على معدل إنتاج الإجنة في الأبقار}

نرمبين عاطف طلمى ، بكار رمضان عبد الحئيم

Email: drbakarwa@yahoo.com

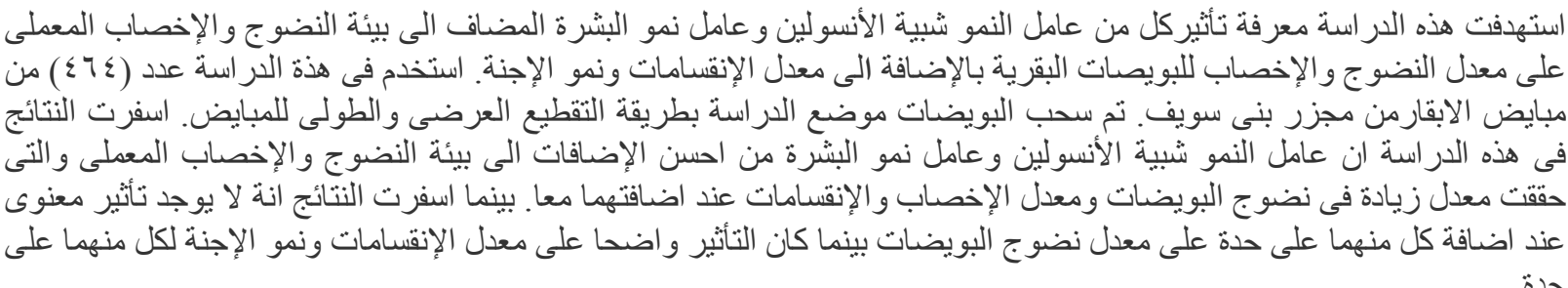

